\title{
PERAN KELUARGA DALAM MEBENTUK KARAKTER ANAK
}

\author{
Samsul Arif \\ Mahasiswa Pascasarjana (S2) Program Studi Pendidikan Agama Islam (PAI) \\ Institut Agama Islam Negeri (IAIN) Jember \\ NIM : 0849317047 \\ Email : samsulariff52@gmail.com
}

\begin{abstract}
Abstrak
Islam is considered as an early religious education because education for children is one of the main goals in the development of Islam. Family is the onset for children to grow and develop. The growth and development of children is characterized by maturity of organs from the age of the baby to adulthood. Meanwhile, family also constitutes an important part for children's education, especially in terms of character building and personality. Discussion about the development of children's character and personality means we face a situation where culture and lifestyle of parents are highly influential in the process. The closest environment has the strongest influence in forming children's habits. The problems of this study were formulated as follows: 1. what is the role of the family in shaping children's character? 2. What efforts does the family make in children's character building? The purpose of this study is to describe the role and efforts of the family in shaping the character of children. The approach used was qualitative involving library research (literature). The results of the study showed that the role of the family in building children's character can be done through hearing, vision and the heart. While efforts that can be made by the family in shaping children's character can be done through prompting aqeedah, teaching worship, raising social values, giving supervision and attention as well as maintaining physical and mental health.
\end{abstract}

Kata Kunci: Peran Keluarga, Karakter Anak

\section{PENDAHULUAN}

Sangat banyak paparan dan penjelasan di dalam Al-Qur'an maupun Hadits Nabi Muhammad SAW, yang sangat erat kaitannya dengan berbagai nasihat, aturan, dan cara mendidik anak secara baik. Karena pendidikan anak merupakan salah satu tujuan utama agama Islam. Oleh karena itu agama Islam dikatakan sebagai agama tarbiyah. Rumah merupakan lingkungan awal bagi anak untuk tumbuh dan berkembang, khususnya dalam perkembangan organorgan tubuhnya, dan di sinilah pusat terpenting bagi pendidikan anak, khususnya dalam pembentukan karakter bagi anak. 
Anak adalah amanah dari Allah sebagai cahaya masa depan, ibarat pundi kosong, anak akan menerima air jenis apa saja yang masuk dalam kantong ajaran kehidupan, untuk kemudian ia akan kembangkan dalam perjalanan hidup pribadinya. Keluarga, lingkungan, dan lembaga pendidikan menjadi pilar yang akan mengisi pundi kosong tersebut, dan menentukan seberkualitas apakah pribadi yang dihasilkan.

Ketika berbicara tentang anak, maka akan dihadapkan pada pola dan budaya anak, yang mana pola dan budaya anak tak akan jauh dari pola hidup orang tua dan lingkungannya. Karena lingkungan terdekat anak akan menciptakan suatu kebiasaan, sehingga anak akan merasa nyaman dengan dunia tersebut. Maka peran keluarga dan lingkungan terdekat anak dinilai sangat penting dan berharga dalam menanamkan nilai-nilai kebaikan. Tentu kebaikan menurut ajaran Allah SWT, dan bukan sekedar kebaikan berdasarkan penilaian baik buruk orang sekitar. Rumusan masalah penenlitian 1 . Bagaimana peran keluarga dalam membentuk karakter Anak?, 2. Upaya apa yang dilakukan keluarga dalam membentuk karakter anak? Tujuan penelitian ini adalah untuk mendeskripsikan peran dan upaya keluarga dalam membentuk karakter anak.

\section{METODE PENELITIAN}

Penelitian ini adalah penelitian studi teks atau studi pustaka. Studi teks menurut Noeng Muhadjir (Arikunto,1998:114) mencakup: pertama, telaah teoritik suatu disiplin ilmu yang perlu dilanjutkan secara empirik untuk memperoleh kebenaran secara empirik pula. Kedua, studi yang berupaya mempelajari seluruh obyek penelitian secara filosofis atau teoritik dan terkait dengan validitas. Ketiga, studi yang berupaya mempelajari teoritik linguistic. Keempat, adalah studi karya sastra. Adapun penelitian ini lebih dekat dengan jenis studi pustaka yang pertama dimana studi ini berusaha menelaah peran keluarga dalam membentuk karakter anak dalam segi agama dan hukum positif . tentunya penelitian ini akan membantu bagi para orang tua agar lebih memperkenalkan pendidikan sejak dini dan membantu dalam setiap proses tumbuh kembang anak. Dimana anak akan selalu melihat setiap apapun yang diajarkan orang tua kepada mereka.

\section{PEMBAHASAN DAN HASIL PENELITIAN}

\section{Peran Keluarga Dalam Membentuk Karakter Anak \\ Lingkungan keluarga, lingkungan} sekolah, dan lingkungan masyarakat merupakan tiga pusat pendidikan, dan keluarga merupakan lingkungan paling pertama yang dapat memberikan pengaruh pada anak. Keluarga juga merupakan lingkungan yang paling kuat dibandingkan dengan lingkungan pendidikan yang lainnya, karena keluarga tempat di mana anak terlahir ke dunia ini.

Dalam buku Prophetic Parenting, Cara Nabi Muhammad SAW Mendidik Anak oleh Suwaid (2010:46) Imam Ghozali mengatakan anak adalah amanat di tangan kedua orang tuanya. Hatinya yang suci adalah mutiara yang masih mentah, melum dipahat maupun dibentuk. Mutiara ini dapat dipahat dalam bentuk 
apa pun, mudah condong kepada segala sesuatu. Apabila dibiasakan dan diajari dengan kebaikan, maka dia akan tumbuh dalam kebaikan itu, dan sebaliknya apabila dibiasakan dengan keburukan dan dilalaikan maka anak akan celaka dan binasa.

Islam terus mendorong agar keluarga dapat menjadi basis utama pendidikan bagi seluruh anggota masyarakat. Hal ini juga tercermin dalam semangat ajaran agama Islam yang menginginkan agar kehidupan rumah tangga selalu dalam kondisi tenang, stabil, rukun dan harmonis (Syantut, 2007:24).

Oleh sebab itu Rasulullah SAW memberikan tanggung jawab anak kepada kedua orang tuanya sebagai tanggung tawab yang penuh. Sebagaimana sabda Rasulullah SAW yang artinya :

"Telah menceritakan kepada kami Musaddad telah menceritakan kepada kami Yahya dari 'Ubaidulloh berkata, telah menceritakan kepadaku Nafi' dari 'Abdullah radliallahu 'anhu bahwa Rasulullah shallallahu 'alaihi wasallam bersabda: "Setiap kalian adalah pemimpin dan akan diminta pertanggung jawaban atas yang dipimpinnya. Amir (kepala Negara), dia adalah pemimpin manusia secara umum, maka dia akan diminta pertanggung jawaban atas mereka. Seorang suami dalam keluarganya adalah pemimpin dan akan diminta pertanggung jawaban atas mereka. Seorang isteri adalah pemimpin di dalam rumah tangga suaminya dan terhadap anak-anaknya dan dia akan diminta pertanggung jawaban atas mereka. Seorang hamba sahaya adalah pemimpin dalam urusan harta tuannya dia akan diminta pertanggung jawaban atasnya. Ketahuilah bahwa setiap kalian adalah pemimipin dan setiap kalian akan diminta pertanggung jawaban atas siapa yang dipimpinnya”
Manusia dilahirkan dalam keadaan fitrah, seorang bayi yang dilahirkan bagaikan selembar kertas putih yang belum ada setitikpun tinta. Kedua orang tua merupakan pendidik pada salah satu pusat pendidikan yaitu lingkungan keluarga, dan keluargalah orang pertama yang akan memberikan tinta di atas kertas tersebut. Pandangan ini sesuai dengan sabda rasulullah SAW yang artinya :

"Telah menceritakan kepada kami Qutaibah bin Sa'id telah menceritakan kepada kami 'Abdul 'Aziz Ad Darawadri dari Al 'Ala dari bapaknya dari Abu Hurairah, Rasulullah bersabda: "Setiap anak itu dilahirkan dalam keadaan fitrah lalu kedua orang tuanyalah yang menjadikannya sebagai seorang yahudi, nasrani dan majusi. Apabila kedua orang tuanya muslim, maka anaknya pun akan menjadi muslim. Setiap bayi yang dilahirkan dipukul oleh syetan pada kedua pinggangnya, kecuali Maryam dan anaknya"

Dapat dikatakan juga bahwa anak yang baru dilahirkan merupakan manusia yang primitif, yang semula tidak mengetahui apa-apa, tidak memiliki pengetahuan, lalu mereka belajar dan berkembang dengan bantuan orang-orang yang ada di sekitarnya, sehingga panca indra yang dimiliki setiap anak yang baru dilahirkan dapat bekerja dengan baik. Pola asuh dan pola didik pada anak merupakan suatu yang sangat penting untuk dilakukan oleh setiap orang tua, mengingat pada masa-masa tersebut anak tengah mengalami pertumbuhan dan perkembangan fisik, motorik dan gerak, akan tetapi yang perlu diketahui dan dipahami oleh para orang tua adalah tentang hakekat anak itu sendiri. Banyak orang yang memandang anak sebagai 
orang dewasa dalam bentuk kecil, akibatnya mereka seringkali menyikapi anakseperti menyikapi orang dewasa atau mereka membiarkan anak tumbuh dan berkembang dengan sendiri, tanpa bantuan dan bimbingan. Sikap yang seperti itu jelasa tidak benar, bahkan sangat berbahaya bagi perkembangan kepribadian anak.

Dalam dunia pendidikan, ada beberapa tokoh yang mengungkapkan konsep teori pemahaman dan pendidikan tentang anak. Salah satunya teori Nativisme yang dipelopori oleh Schoupenhouer, teori ini berkesimpulan bahwa hakekatnya anak adalah orang dewasa yang berbentuk kecil. Campur tangan manusia terhadap pertumbuhan dan perkembangannya justru akan membuat rusaknya anak, biarkan alam lingkungan yang mendidiknya. Dengan demikian pendidikan cukup menyediakan lingkungan yang sekondusif mungkin terhadap pertumbuhan dan perkembangan anak (Cholil, 2011:66).

Untuk membentuk karakter pada anak dapat dilakukan dengan kepedulian dan keteladanan orang tua dengan cara memperkenalkannya sejak dini dan mendampinginya. Struktur terkecil dalam masyarakat ini menjadi kunci awal dalam pembentukan nilai karakter pada anak. Keluarga adalah pembentuk paling signifikan dalam diri seseorang. Anak mengenal arti baik dan buruk dari keluarga melalui apa yang sering dilihat, didengar dalam keluarga, ucapan, tindakan yang ditampilkan khususnya oleh orang tua.

Kita mengenal istilah bahasa arab "al uтmu madrasatul ula" ibu adalah tempat pendidikan pertama dalam kehidupan seseorang. Ibu sebagai simbol keluarga, dan rumah awal kehidupan merupakan sejarah pembangun nilai dan karakter anak, sehingga sebuah ungkapan menyatakan : "jika di rumah penuh dengan celaan, maka anak akan terbiasa memaki. Jika di rumah penuh dengan permusuhan, maka anak akan belajar berkelahi. Jika di rumah penuh dengan olok-olok, maka anak belajar rendah diri. Jika di rumah penuh dengan iri hati, maka anak belajar kedengkian. Jika di rumah selalu dipermalukan, maka anak belajar merasa bersalah. Jika di rumah penuh dengan dorongan, maka anak belajar percaya diri, dan seterusnya".

Pada pembahasan ini, penulis akan memaparkan analisis peran keluarga dalam membentuk karakter anak sesuai dengan ayat-ayat yang dikaji yaitu pada surat An-Nahl ayat 78. Ayat ini menggambarkan bagaimana anak dilahirkan dalam keadaan tidak mengetahui apa-apa, akan tetapi Allah telah memberikan bekal, yakni pendengaran, penglihatan dan hati, karena anak dilahirkan dalam lingkungan keluarga, maka disinilah tanggung jawab keluarga untuk mendidik dan mengembangkan apa yang dimiliki anak.

Dalam hal ini, untuk menanamkan karakter pada anak dapat melalui tiga cara berikut ini :

\section{Melalui Pendengaran}

Dalam surat An-Nahl ayat 78 terdapat kata As-sam'u yang memiliki arti pendengaran. Pendengaran adalah suatu alat yang diberikan Allah SWT pada manusia, pendengaran berfungsi untuk menyerap informasi melalui suara yang ada di sekitarnya. Untuk menanamkan 
karakter yang baik pada anak, maka yang harus dilakukan setiap keluarga adalah dengan melalui pendengaran pada setiap anak yakni memberi nasehat yang baik (Mauidzah hasanah), mauidzah merupakan nasehat yang mampu menyentuh kalbu dan menumbuhkan semangat beramal. Maka dengan mauidzah akan tercipta karakter yang baik pada anak.

Dalam hal ini, Jauhari (2006 : 65) menyatakan bahwa dalam menyampaikan mauidzah Rasulullah telah menjelaskan dalam hadisnya yanga artinya :

"Rasulullah SAW, bersabda : kita diperintahkan untuk selalu berbicara dengan manusia menurut kemampuan akalnya (HR. Muslim)".

Jadi, sebagai orang tua harus dapat memilah dan memilih kata-kata dalam memberikan nasehatnya, karena setiap kata yang keluar dari apa yang diucapkan orang tua kepada anak akan cepat ditangkap dan melekat pada ingatan anak tersebut.

Ucapan bukanlah penentu pembentukan karakter pada anak, tapi harus disadari bahwa ucapan juga memiliki peranan penting dalam pembentukan karakter pada anak, karena anak akan dapat menirukan apa yang diucapkan oleh orang sekitar khususnya kedua orang tuanya, olehsebab itu sebagai orang tua alangkah baiknya mengucapkan perkataan yang baik pada anak.

Islam telah mengajarkan untuk mengadzani bayi yang baru dilahirkan karena disitu terdapat hikmah yang begitu besar, sebagai mana yang telah diungkapkan Ibnu Qayyim dalam buku Prophetic Parenting, Cara Nabi Mendidik
Anak oleh Suwaid (2010:103) mengatakan :

a) Agar ucapan pertama yang masuk ke dalam telinga manusia adalah katakata yang mengungkapkan sifat-sifat kebesaran Allah, keagungan-Nya, dan syahadat yang menjadi syarat sah masuk Islam. Itu semua menjadi seperti talqin bagi si bayi dengan syiar Islam ketika dia masuk ke dalam kehidupan dunia, sebagaimana nantinya dia juga akan ditalqin dengan kalimat tauhid ketika keluar dari dunia.

b) Harus diakui tentang sampainya dampak adzan ini ke dalam hari si bayi walaupun dia tidak merasakannya.

c) Kaburnya setan karena mendengar adzan. Sebelumnya, setan ini mengintai si bayi sampai dia dilahirkan, kemudian mengikutinya untuk menggodanya sebagai aplikasi ketentuan dan kehendak Allah SWT. Maka, disaat pertama kali ada keterkaitan dengan si bayi ini, setan sudah harus mendengar suatu yang dapat melemahkannya dan membuatnya gusar.

d) Ajakan kepada Allah, kepada agama Islam dan kepada beribadah kepadaNya harus mendahului ajakan setan. Sama seperti fitrah Allahyang digariskan bagi umat manusia, yakni selalu mendahului perubahan fitrah yang dilakukan oleh setan dan hikmah-hikmah terpendam lainnya.

Islam juga telah mengajarkan untuk memberikan nama yang baik bagi bayi yang dilahirkan, karena dengan nama yang baik memiliki dampak yang positif pada jiwa dari pertama kali 
mendengarnya. Gambaran tentang aspek pendengaran disini adalah mengindahkan pemberian nama-nama bagi anak sehingga ketika dipanggil dengan nama tersebut terdengar indah. Konsep ini sesuai dengan sabda rasulullah SAW yang artinya :

"Rasulullah SAW, bersabda : Pakailah nama-nama para Nabi. Nama yang paling dicintai Allah adalah Abdullah dan Abdurrahman. Nama yang paling jujur adalah Harits (orang yang memiliki keinginan) dan Hammam (orang yang memiliki cita-cita). Nama yang paling buruk adalah Harb dan Murrah" (HR. Abu Dawud dan Nasa'i).

"Rasulullah Shollallahu álaihi wa sallam bersabda : sesungguhnya pada hari kiamat kelak kalian akan dipanggil dengan nama kalian dan nama bapak kalian. Oleh karena itu, indahkanlah nama kalian (HR. Abu Dawud dan Abu Darda')".

\section{Melalui Penglihatan}

Kata yang terdapat dalam surat AnNahl ayat 78 setelah As-sam' $u$ adalah $A l$ Abshoru yang artinya penglihatan. Bagaimanapun juga orang tua adalah panutan bagi anak, materi yang baik tidak akan mampu diterima oleh anak, apabila para penyampai materi tersebut tidak mencerminkan apa yang disampaikan.

Oleh karena itu, sebagai orang tua harus memberikan teladan yang baik kepada anaknya. Keteladanan sikap yang baik merupakan langkah penting dalam membentuk karakter sebagai pribadi yang unggul, karena anak adalah peniru ulang dalam setiap hal baik positif maupun negatif. Sebagaimana sabda rasulullah SAW artinya :

"Maka Rasulullah SAW bersabda: "Barangsiapa yang memulai mengerjakan perbuatan baik dalam Islam, maka dia akan memperoleh pahalanya dan pahala orang yang mencontoh perbuatan itu, tanpa mengurangi pahala mereka sedikitpun. Dan barangsiapa yang memulai kebiasaan buruk, maka dia akan mendapatkan dosanya, dan dosa orang yang mengikutinya dengan tanpa mengurangi dosa mereka sedikit pun".

Perspektif ini dipertegas dalam firman Allah Q.S. Al-Ahzab yang artinya :

"Sesungguhnya telah ada pada (diri) Rasulullah itu suri teladan yang baik bagimu (yaitu) bagi orang yang mengharap (rahmat) Allah dan (kedatangan) hari kiamat dan Dia banyak menyebut Allah"(Departemen Agama RI,2006:420).

Perlu diketahui, bahwa anak kebanyakan meniru apa yang dilakukan orang tuanya. Teladan yang baik memiliki peran yang begitu besar terhadap perkembangan anak. Karena anak mudah menirukan apa yang dilakukan oleh orang di sekitarnya, terutama apa yang menjadi perilaku kedua orang tuanya. Sebagaimana sabda Rasulullah SAW yang artinya:

"Telah menceritakan kepada kami Adam telah menceritakan kepada kami Ibnu Abu Dza'bi dari Az Zuhriy dari Abu Salamah bin 'Abdurrahman dari Abu Hurairah berkata; Rasulullah SAW, bersabda: "Setiap anak dilahirkan dalam keadaan fithrah. Kemudian kedua orang tunyalah yang akan menjadikan anak itu menjadi Yahudi, Nashrani atau Majusi sebagaimana binatang ternak yang melahirkan binatang ternak dengan sempurna. Apakah kalian melihat ada cacat padanya".

Suwaid dalam buku Prophetic Parenting cara Nabi mendidik anak yang di terjemahkan oleh Qurusy (2010:139) mengemukakan bahwa Rasulullah SAW, memerintahkan kedua orang tua untuk menjadi teladan yang baik dalam bersikap 
dan bertindak, serta berperilaku jujur dalamberhubungan dengan anak. Sebagaimana hadits Rasulullah SAW yang diriwayatkan oleh Imam Ahmad dari Abu Hurairah ra yang artinya :

"Telah menceritakan kepada kami Hajjaj telah menceritakan kepada kami Laits telah menceritakan kepadaku 'Uqail dari Ibnu Syihab dari Abu Hurairah dari Rasulullah shallallahu 'alaihi wasallam, bahwasanya beliau bersabda: "Barangsiapa mengatakan kepada anak kecil; 'Kemarilah aku beri sesuatu, namun ia tidak memberinya maka ia telah berbohong".

Anak-anak akan selalu memperhatikan dan meneladani sikap dan perilaku orang dewasa. Apabila mereka melihat kedua orang tuanya berperilaku jujur, mereka akan tumbuh dalam kejujuran. Demikian seterusnya (Suwaid, 2010:140).

Ketika anak sudah bisa melihat apa yang dilakukan oleh orang tuanya, seperti melakukan shalat dan membaca Al-Qur'an, anak seusia ini harus diikutsertakan dalam kegiatan shalat berjamaah di rumah. Ajaklah anak untuk duduk bersama, menyimak dan mendengarkan bacaan Al-Qur'an atau do'a-do'a yang dibacakan oleh orang tuanya (Syantut,2007:96).

\section{Melalui Hati}

Hati akan membentuk karakter seseorang, karena Rasulullah SAW, pernah berpesan kepada para sahabatnya, bahwasannya di dalam diri manusia itu terdapat hati yang harus diutamakan dan di jaga, apabila hatiitu baik maka baiklah tubuh tersebut, dan sebaliknya. Fakta ini sesuai dengan sabda rasulullah SAW yang artinya :
"Telah menceritakan kepada kami Abu Nu'aim Telah menceritakan kepada kami Zakaria dari 'Amir berkata; aku mendengar An Nu'man bin Basyir berkata; aku mendengar Rasulullah SAW, bersabda: "Yang halal sudah jelas dan yang haram juga sudah jelas. Namun diantara keduanya ada perkara syubhat yang tidak diketahui oleh banyak orang. Maka barangsiapa yang menjauhi diri dari yang syubhat berarti telah memelihara agamanya dan kehormatannya. Dan barangsiapa yang sampai jatuh (mengerjakan) pada perkara-perkara syubhat, sungguh dia seperti seorang penggembala yang menggembalakan ternaknya di pinggir jurang yang dikhawatirkan akan jatuh ke dalamnya. Ketahuilah bahwa setiap raja memiliki batasan, dan ketahuilah bahwa batasan larangan Allah di bumi-Nya adalah apaapa yang diharamkan-Nya. Dan ketahuilah pada setiap tubuh ada segumpal darah yang apabila baik maka baiklah tubuh tersebut dan apabila rusak maka rusaklah tubuh tersebut. Ketahuilah, ia adalah hati”.

Menurut Nashori (2003:114) menerangkan bahwa Qalbu merupakan materi organik yang memiliki sistem kognisi yang berdaya emosi. Ia berada di jantung. Qalbu memiliki kemampuan untuk memperoleh pengetahuan melalui cita-rasa. Allah berfirman dalam AlQurean surat Al-Taghabun ayat 11 yang artinya :

"Tidak ada suatu musibah pun yang menimpa seseorang kecuali dengan ijin Allah; dan Barangsiapa yang beriman kepada Allah niscaya Dia akan memberi petunjuk kepada hatinya. dan Allah Maha mengetahui segala sesuatu" (Departemen Agama RI, 2006:557).

Orang tua harus mempersiapkan dirinya secara keseluruhan, baik lahir maupun batin. Harus memiliki sifat kasih 
sayang, khususnya kepada anak-anaknya tanpa membeda-bedakan, dengan tidak pilih kasih terhadap anaknya.Do'a adalah cermin hati yang merefleksikan cinta dan kasih sayang. Do'a adalah bukti hati yang berbakti, hati yang penuh dengan cinta akan selalu melantunkan do'a yang terucap di lidah seperti keluar-masuknya nafas. Semakin bertambah rasa cinta dan kasih sayang antara kedua orang tua dengan anak, maka semakin banyak pula do'a yang diucapkan (Suwaid,2010:246), sesuai dengan sabda rasulullah SAW yang artinya :

"Telah menceritakan kepada kami Abu Bakar telah menceritakan kepada kami Abdullah bin Bakr As Sahmi dari Hisyam Ad Dastuwa i dari Yahya bin Abu Katsir dari Abu Ja'far dari Abu Hurairah dia berkata; Rasulullah shallallahu 'alaihi wasallam bersabda: "Tiga macam do`a yangakan di kabulkan dan tidak ada keraguan pada ketiganya, yaitu; do'a orang yang di dzalimi, do'anya orang musafir dan do'a orang tua kepada anaknya”.

Serupa dengan pernyataan di atas bahwasannya ketiga piranti tersebut dapat dibina dan dibimbing sehingga menghasilkan suatu perilaku yang nantinya dapat terbentuknya karakter yang baik pada anak. Perilaku-perilaku yang menggambarkan surat An-Nahl ayat 78 yakni selalu bersikap rendah hati, selalu menggunakan akal, pikiran dan hati nurani, serta selalu menjaga keimanan dan ketakwaan kepada Allah SWT.

\section{Upaya Keluarga Dalam Membentuk Karakter Anak}

Berkaitan dengan hal tersebut, maka terdapat beberapa upaya yang harus dilakukan setiap keluarga dalam membentuk karakter anak sebagai berikut

\section{Menanamkan Nilai Akidah}

Menanamkan akidah merupakan pokok dasar manusia dalam menjalani kehidupan di dunia ini. Membangun dan menanamkan nilai-nilai akidah pada diri anak inilah yang harus dilakukan oleh setiap orang tua, yakni dengan menanamkan keyakinan bahwa Allah itu maha esa beserta sifat-sifat yang mulia. Dalam hal ini telah dicontohkan oleh lukman hakim yang diabadikan Allah dalam Al-Qur'an yang artinya :

"Dan (ingatlah) ketika Luqman berkata kepada anaknya, di waktu ia memberi pelajaran kepadanya: "Hai anakku, janganlah kamu mempersekutukan Allah SWT, Sesungguhnya mempersekutukan (Allah) adalah benar-benar kedzaliman yang besar"(Departemen Agama RI, 2006:412)

Langkah yang harus dilakukan dalam menanamkan nilai-nilai aqidah pada anak yakni dengan membiasakan anak mendengarkan lantunan ayat-ayat Al-Qur'an, ceramah agama, kalimah toyyibah, serta ucapan-ucapan yang sopan dan santun dari orang sekitarnya.Mengumandangkan adzan pada anak yang baru dilahirkan merupakan salah satu cara menanamkan akidah pada anak sejak dini, seperti sabda rasulullah SAW yang artinya :

'Telah menceritakan kepada kami Waki' dia berkata, telah menceritakan kepada kami Sufyan dari 'Ashim bin 'Ubaidullah dari 'Ubaidullah bin Abu Rafi' dari dari ayahnya, bahwa Nabi SAW, mengumandangkan adzan pada telinga Hasan bin 'Ali ketika Fatimah melahirkannya". 
Dengan mengumandangkan adzan pada anak yang baru dilahirkan, Ibnu Qayyim Ra berpendapat bahwa rahasia dilakukan adzan mengandung harapan yang optimis, agar pertama kali yang terdengar di telinga bayi adalah seruan Adzan yang mengandung makna keagungan dan kebesaran Allah SWT. serta syahadat yang menjadi sarat utama bagi seseorang yang baru pertama kali masuk Islam (Rif'ani, 2013:45).

Adzan yang dikumadangkan pada anak yang baru dilahirkan dapat juga untuk mengusir setan yang selalu berupaya mengganggu sang bayi semenjak kelahirannya dan memulai kehidupan barunya di dunia. Rasulullah bersabda yang artinya "jika diserukan adzan untuk shalat, setan lari terbirit-birit dengan mengeluarkan kentut sampai tidak mendengar seruan adzan"(HR. Abu Dawud dan Tirmidzi).

\section{Menanamkan Nilai Ajaran Ibadah}

Menanamkan ajaran ibadah ini merupakan salah satu langkah untuk menyempurnakan penanaman nilai-nilai akidah. Karena hakekat ibadah sebagaimana yang dikatakan Al-Imam Ibnu Katsir dalam tafsirnya :

"Ibadah itu ialah suatu pengertian yang mengumpulkan kesempurnaan cinta, tunduk dan takut" (Ash-Shiddiqy,2000:9).

Sebagaimana penjelasan yang diutarakan oleh Ibn Katsir tersebut, ibadah merupakan suatu tatanan yang mengatur hidup manusia sebagai hamba Allah yang harus tunduk, takut dan patuh kepadaNya. Kecintaan, ketundukan dan patuh senantiasa dibuktikan dalam melaksanakan ibadah yang sudah diatur dalam syariat Islam, serta senantiasa takut akan siksaNya kelak di akhirat apabila tidak tunduk dan patuh terhadap syariat yang sudah ditetapkan.

Secara umum, ibadah berarti mencakup semua perilaku dalam kehidupan manusia yang sesuai dengan ketentuan yang telah ditetapkan Allah SWT. oleh sebab itu orang tua perlu menanamkan nilai ibadah inipada anak, karena ibadah ini merupakan bentuk kecintaan dan ketundukan kepada Allah SWT.

\section{Menanamkan Nilai Sosial}

Manusia adalah makhluk sosial, dimana Allah menciptakan manusia agar melakukan interaksi sosial. Dalam berinteraksi dengan lingkungan sosialnya, dianjurkan kepada kita untuk menampilkan akhlak sosial yang baik (Prayitno, 2004: 51).

Rasulullah SAW, dalam banyak sabdanya telah mengajarkan bagaimana berinteraksi dengan orang lain dalam berbagai tingkat usia. Bagaimana cara berinteraksi dengan orang tua, dengan anak muda bahkan dengan teman sebaya dan anak-anak, dengan upaya ini maka akan tercipta sifat dan karakter anak berjiwa sosial.

Sejak terlahirnya anak kedunia ini hingga genap berusia dua tahun, sudah harus ditanamkan jiwa bermasyarakat pada diri anak. Pendidikan bermasyarakat yang dilakukan sejak usia dini akan membekas sepanjang masa (Syantut, 2007:32). 
4. Memberikan Pengawasan

dan

\section{Perhatian}

Perhatian merupakan suatu

keadaan yang mengungkapkan suatu perasaan, mengungkapkan rasa cinta yang sifatnya sangat kuat dan penuh kelembutan. Cinta orang tua kepada anak adalah cinta yang murni, tanpa belas jasa, cinta orang tua terhadap anaknya benarbenar diberikan atas dasar kepada kepentingan anaknya, cinta orang tua yang tulus akan menjadi dasar bagi pembentukan karakter pada anak.

Dengan selalumencurahkan perhatian penuh dengan mengikuti aspek akidah, dan moral anak, mengawasi dan memperhatikan kesiapan mental dan sosial.Islam dengan keuniversalan prinsipnya dan peraturannya yang abadi, memerintahkan para bapak, ibu dan pendidik untuk memperhatikan dan senantiasa mengikuti serta mengawasi anak-anaknya dalam segala segi kehidupan dan pendidikan yang universal (Ulwan,1999:275).

Perhatian dan pengawasan Rasulullah SAW, yang dilakukan terhadap setiap orang di dalam masyarakat, telah menggariskan kepada para pendidik suatu metode luhur dalam pendidikan, tatacara efektif dan berpengaruh dalam bimbingan. Oleh sebab itu, mereka harus berusaha sekuat tenaga dalam mencurahkan segala perhatiannya untuk membahagiakan dan memperbaiki anak, termasuk meninggikan derajat mereka dari segi mental, spiritual dan moral.

Apabila perhatian dan pengawasan yang nyata dapat memberikan manfaat untuk manusia dewasa, maka anak kecil tentu akan lebih bermanfaat. Sebab, anak kecil memiliki kecenderungan kepada kebaikan, kesiapan fitrah, kejernihan jiwa, yang tidak dimiliki manusia dewasa.

Dengan kata lain, anak sangat mudah untuk menjadi baik dan terbentuk karakter yang baik pula, jika memang tersedia faktor lingkungan yang baik dalam rumah, sementara itu pendidik akan mendapatkan kesulitan dalam memperbaiki anak, jika kaum dewasa adalah kaum yang tidak memberikan perhatian dan pengawasannya (Ulwan,1999:287).

\section{Menjaga Jasmani dan Kesehatan}

Keluarga juga memiliki peranan penting dalam pertumbuhan jasmani anak, baik dalam aspek perkembangan maupun aspek pertumbuhan. Asupan gizi yang baik merupakan kebutuhan anak yang harus dipenuhi oleh setiap orang tua.Agama Islam memberikan perhatian besar terhadap kesehatan manusia secara umum, khususnya kesehatan anak-anak.

Banyak sekali anjuran dalam Islam untuk segera berobat. Sebab, berobat adalah penyembuhan mendasar bagi kesehatan tubuh (Suwaid, 2010:524), seperti sabda Rasulullah SAW :

"Telah menceritakan kepada kami Abu Bakr bin Abu Syaibah dan Ibnu Numair mereka berdua berkata; telah menceritakan kepada kami 'Abdullah bin Idris dari Rabi'ah bin 'Utsman dari Muhammad bin Yahya bin Habban dari Al A'raj dari Abu Hurairah dia berkata; "Rasulullah SAW, bersabda: Orang mukmin yang kuat lebih baik dan lebih dicintai oleh Allah SWT, daripada orang mukmin yang lemah. Pada masing-masing 
memang terdapat kebaikan. Capailah dengan sungguh-sungguh apa yang berguna bagimu, mohonlah pertolongan kepada Allah SWT, dan janganlah kamu menjadi orang yang lemah. Apabila kamu tertimpa suatu kemalangan, maka janganlah kamu mengatakan; "Seandainya tadi saya berbuat begini dan begitu, niscaya tidak akan menjadi begini dan begitu.".

\section{KESIMPULAN}

Kesimpulan yang dapat diambil dari deskripsi diatas sebagai berikut :

1. Peran keluarga dalam membentuk karakter anak dapat dilakukan melalui : melalui pendengaran, penglihatan dan hati

2. Upaya keluarga dalam membentuk karakter anak dapat dilakukan dengan menanamkan nilai aqidah, nilai dan ajaran ibadah, nilai sosial, meberikan pengawasan dan perhatian serta menjaga jasmani dan kesehatan.

\section{DAFTAR PUSTAKA}

Cholil, Moh. Hasyim. (2011). Filsafat Pendidikan Islam. Surakarta.

Departemen agama RI. (2006). Al-Qur"an Maghfirah. Terjemahan, Asbabun Nuzul, Hadis seputar ayat, Hikmah, Indeks Tematik. Jakarta: Maghfirah Pustaka.

Jauhari, Moh. Idris. (2006). Pelajaran Adab Sopan Santun. Sumenep: Mutiara Press.

Nashori, H. Fuad. (2003). Potensi Potensi Manusia. Seri Psikologi Islam. Yogyakarta: Pustaka Pelajar.

Prayitno, H. Irawan. (2004). Anakku Penyejuk Hatiku. Panduan Bagi
Orang Tua dan Guru. Pondok Gede Bekasi: Pustaka Tarbiatuna.

Rif'ani, Nur Kholish. (2013). Cara Bijak Rasulullah Dalam Mendidik Anak sejak dalam kandungan-18 Tahun. Sleman Yogyakarta: Real Books.

Shihab, M. Quraish. (2010). Mendidik Anak Ala Rasulullah. Jakarta: Majalah Qalam

Suwaid, Muhammad Nur Abdul Hafizh. (2009). Prophetic Parenting, Cara Nabi Mendidik Anak. Diterjemahkan oleh: Farid Abdul Aziz Qurusy. 2010. Yogyakarta: Pro-U Media.

Syantut, Khalid Ahmad. (2007). Melejitkan Potensi Moral dan Spiritual Anak. Panduan Mendidik Anak Prasekolah. Bandung: Syaamil Cipta Media.

Ulwan, Abdullah Nasih. (1994). Pendidikan Anak Dalam Islam. Terjemahan oleh. Jamaludin Miri. 1999. Jakarta: Pustaka Amani. 
